\title{
Unusual Cases of Adult Intersexuality in the European Eel Anguilla anguilla
}

\author{
B. Geffroy ${ }^{a, b} \quad$ A. Fostier ${ }^{c} \quad$ Y. Guiguen ${ }^{c} \quad$ A. Bardonnet ${ }^{a, b}$
}

aINRA, UMR1224 Ecobiop, Aquapôle, Saint Pée sur Nivelle, b Université Pau and Pays Adour, UMR1224 Ecobiop, UFR des Sciences de la Côte Basque, Anglet, and 'INRA, UR1037 LPGP, Fish Physiology and Genomics, SFR Biosit, Biogenouest, Rennes, France

\section{Key Words}

Aromatase $\cdot$ European eel $\cdot$ Hermaphrodite $\cdot$ Intersex

\begin{abstract}
Two cases of intersexuality are reported for the first time in European eel, Anguilla anguilla (at the beginning of the silver eel stage), within 140 fish caught as glass eels in the southwest of France and reared in tanks at $17^{\circ} \mathrm{C}$. Cysts containing spermatozoa were observed in ovaries with pre-vitellogenic oocytes. This feature is very uncommon, especially owing to the fact that male cells do not normally reach this stage in captivity, and an environmentally controlled transdifferentation process may not be excluded. Besides, the expression of the gonadal aromatase gene (cyp19a1a) was found to be higher in these 2 intersexual fish compared to normal females, although these results must be considered with caution since only 2 intersexual fish were available. A possible feminizing effect of this 'abnormal' upregulation of aromatase is discussed.

Copyright $\odot 2012$ S. Karger AG, Basel
\end{abstract}

Genetic sex determination has been suggested in the 3 major species of temperate eels, i.e. Anguilla anguilla, A. rostrata and $A$. japonica, as in these species a pair of heteromorphic chromosomes has been observed in females [reviewed in Tesh, 2003]. Despite this feature, environmental factors can easily overcome genetic sex determination [Wiberg, 1983; Sola et al., 1984], pointing out the extreme lability of sex differentiation in eels. At the juvenile stage, intersexuality was found to be common in the Anguilla genus [Colombo et al., 1984; Helfman et al., 1987; Kearney et al., 2011]. Indeed, both male and female gonads of the eel $A$. anguilla can develop via a juvenile intersexual intermediate stage known as the Syrski organ. This organ is macroscopically similar to a developing testis but contains some degenerating or normal oocytes [Colombo and Grandi, 1996]. The ovary can also develop directly from the undifferentiated stage according to Colombo and Grandi [1996] and Beullens et al. [1997]. In the present study we found ovarian and testicular tissues in 2 adult specimens at an advanced stage of development in the same gonads. These fishes were called 'adult intersexual' eels (AI) in contrast to 'juvenile intersexuality' which has previously been described. In the past, few AI cases were identified in silver eel $A$. dieffenbachii [Lokman and Young, 1998] and A. japonica [Takahashi and Sugimoto, 1978; Takahashi, 1979; Satoh et al., 1992; Matsubara et al., 2008]. To the best of our knowledge, no such case has been reported for the European eel apart from Olivereau and Olivereau [1985] who described 2 intersexual cases in $A$. anguilla silver eels but only after a masculinizing $17 \alpha$-methyltestosterone treatment. In natural AI cases, male and female tissues were either separated [Takahashi and Sugimoto, 1978] or intermingled [Takahashi and Sugimoto,

\section{KARGER}

Fax +4161306 1234

E-Mail karger@karger.ch

www.karger.com (c) 2012 S. Karger AG, Basel

$1661-5425 / 12 / 0066-0316 \$ 38.00 / 0$

Accessible online at:

www.karger.com/sxd
Agnes Bardonnet

INRA, UMR Ecobiop, Pôle d'Hydrobiologie

Quartier Ibarron

FR-64310 Saint Pée sur Nivelle (France)

E-Mail bardonne@st-pee.inra.fr 
1978; Takahashi, 1979; Satoh et al., 1992; Lokman and Young, 1998]. The 2 AI European eels described in the present study were fortuitously identified during the course of a previous experiment aiming to compare aromatase gene expression between females, males and juvenile intersexual eels. Aromatase is involved in androgen conversion to estrogen and has been shown to be a key enzyme in ovarian differentiation [Guiguen et al., 2010]. Despite the fact that 2 separate aromatase genes, named cyp19a1a and cyp19a1b, have been identified in most teleosts, only a single gene, cyp19a1a, has been found in eels [Tzchori et al., 2004; Jeng et al., 2012]. In the present study, we describe 2 AI cases in A. anguilla and we also compare their gonadal aromatase gene expression (cyp19a1a) to those of normal ovaries.

\section{Material and Methods}

\section{Animals}

All works herein comply with current French national laws on the handling of animals.

Glass eels were caught by professional fishermen in marine water, close to the estuary of Courant d'Huchet (Molliet, SouthWestern France, $43^{\circ} 51^{\prime} \mathrm{N}, 1^{\circ} 23^{\prime} \mathrm{W}$ ) in March 2009. They were transferred to freshwater and reared in tanks supplied with thermo-regulated water $\left(17 \pm 2^{\circ} \mathrm{C}\right)$ in INRA experimental facilities and fed with an artificial eel diet (Biomar, Dan-Ex). The 2 intersexual specimens were detected among 140 eels that were longer than $29 \mathrm{~cm}$, which is known as a threshold for histological sex differentiation [Colombo and Grandi, 1996]. After being anesthetized, and then killed with a lethal dose of benzocaine $(2 \mathrm{ml} / \mathrm{l}$ of water), they were dissected. Two kinds of gonads were usually detected: a female's gonad looking like 'frilled organ' and a male's gonad looking like small 'lobes' [Kuhlmann, 1975]. All females' gonads $(n=25)$ were sampled and analyzed. The left gonad of each fish was immediately frozen in liquid nitrogen and stored at $-80^{\circ} \mathrm{C}$ until RNA extraction. The right gonad was used for histological sex assessment (in all 140 individuals). Gonads were fixed in Bouin's fluid for 6 to $8 \mathrm{~h}$, rinsed in clear water for $1 \mathrm{~h}$ and stocked in a $10 \%$ formaldehyde solution. Each gonad was embedded in paraffin and cut at 5-6 $\mu \mathrm{m}$. Slides were stained with Regaud's hematoxylin, Orange $\mathrm{G}$ and aniline blue automatically (MICROM, HMS 760X) [Gabe, 1968].

\section{RNA Extraction and Real-Time PCR}

Gonads kept for molecular analysis were crushed with a disperser (Ultra-Turrax, IKA). Total RNA of each gonad was extracted using Tri Reagent (Molecular Research Center) according to the manufacturer's instructions. An aliquot of each tube was diluted in diethylpyrocarbonate-treated distilled water to reach the value of $183 \pm 15 \mathrm{ng} / \mu \mathrm{l}$ RNA. Then, $1.8 \mu \mathrm{g}$ of RNA were reverse transcribed using $200 \mathrm{U}$ Moloney murine leukemia virus reverse transcriptase (Promega) and $2 \mu \mathrm{g}$ of random hexamers (Promega) in a master mix containing $2 \mathrm{mM}$ dNTPs, $50 \mathrm{mM}$ Tris- $\mathrm{HCl}, 75 \mathrm{mM}$ $\mathrm{KCl}, 3 \mathrm{mM} \mathrm{MgCl}_{2}$, and $10 \mathrm{mM}$ dithiothreitol $\mathrm{pH}$ 8.3. Afterwards, the mix was supplemented with $25 \mathrm{U}$ of RNase inhibitor (RNasin, Promega). Reverse transcription products were diluted 1:50. Aromatase primers were designed thanks to the Primer3 software and from the sequence given in Tzchori et al. [2004] (forward: 5'-GGAAATCCTTGGAGGATGATGTC-3'; reverse: 5'-TACGCCCAACATTAAGGATGATG-3'). Primers for the reference gene, eukaryotic translation elongation factor 1 alpha 1 (eefla1) (forward: 5'-ATTGTGGGAGTCAACAAGATGGA-3'; reverse: 5'-GCTGACTTCCTTGGTGATTTCCT-3') were designed based on the A. anguilla sequence available in the GenBank (Accession No. EU407825).

Real-time PCR was performed on CDNA, using a kit provided with a SYBR Green fluorophore (Fast SYBR Green Master Mix; Applied Biosystems). Each well contained $4 \mu \mathrm{l}$ of each cDNA, $1 \mu \mathrm{l}$ of primers (diluted 10 times) and $5 \mu$ l of SYBR Green. The realtime PCR was run with the system Step One Plus (Applied Biosystems). The hot start enzyme was activated for $20 \mathrm{~s}$ at $95^{\circ} \mathrm{C}$, then the amplification was carried out using the following cycle: $95^{\circ} \mathrm{C}$ for $3 \mathrm{~s} ; 60^{\circ} \mathrm{C}$ for $30 \mathrm{~s}, 40$ times each. After amplification, a melting curve was obtained according to the following protocol: $10 \mathrm{~s} \mathrm{hold-}$ ing at $55^{\circ} \mathrm{C}$ followed by a $0.5^{\circ} \mathrm{C}$ increase, repeated 80 times. For the present study, aromatase gene expression was only compared between AI gonads and ovaries at the same developing stage (i.e. showing oocytes of different size at the cortical alveoli stage).

\section{Results}

AI gonads were macroscopically classified as ovaries. However, the histological analysis revealed that they contained spermatogonia, many nests of spermatocysts and spermatids as well as some spermatozoa intermingled between oocytes of different sizes (fig. 1). Spermatozoa were found in the gonad of each AI eel. The size of the 2 intersexual specimens were $36.6 \mathrm{~cm}$ at $90 \mathrm{~g}$ (AI1) and $34.8 \mathrm{~cm}$ at $64.5 \mathrm{~g}$ (AI2), respectively. Among true females, we chose those having similar oocyte sizes to AI fish. The lengths of these 10 true females ranged between 32 and $39 \mathrm{~cm}$ and their body weight between 52 and $100 \mathrm{~g}$. Aromatase gene expression in AI eels' gonads was higher than in 9 of the 10 analyzed ovaries (fig. 2), whatever the size.

\section{Discussion}

As far as we know, this is the first study reporting the existence of AI eels at an advanced stage of maturation in $A$. anguilla. The proportion of AI eels was very low, representing $1.4 \%(2 / 140)$ of eels investigated at the microscopic level. This is comparable to what was found in $A$. japonica kept in similar conditions [Satoh et al., 1992]. These authors designed an experiment to assess the effect of an estrogen treatment on sex ratio and found $1.7 \%$ of hermaphrodite eels in the control group. These eels were 
Fig. 1. a Gonads of AI1 specimen and b-d gonads of AI2 specimen showing spermatocytes (sc), spermatids (st) and spermatozoa (sz), together with meiotic cysts (mc) and growing oocytes (go). Scale bar $20 \mu \mathrm{m}$.

Fig. 2. Aromatase gene (cyp19ala) expression in 10 ovaries (empty bars) of true females and 2 gonads of AI eels (grayed bars) relative to eeflal expression.
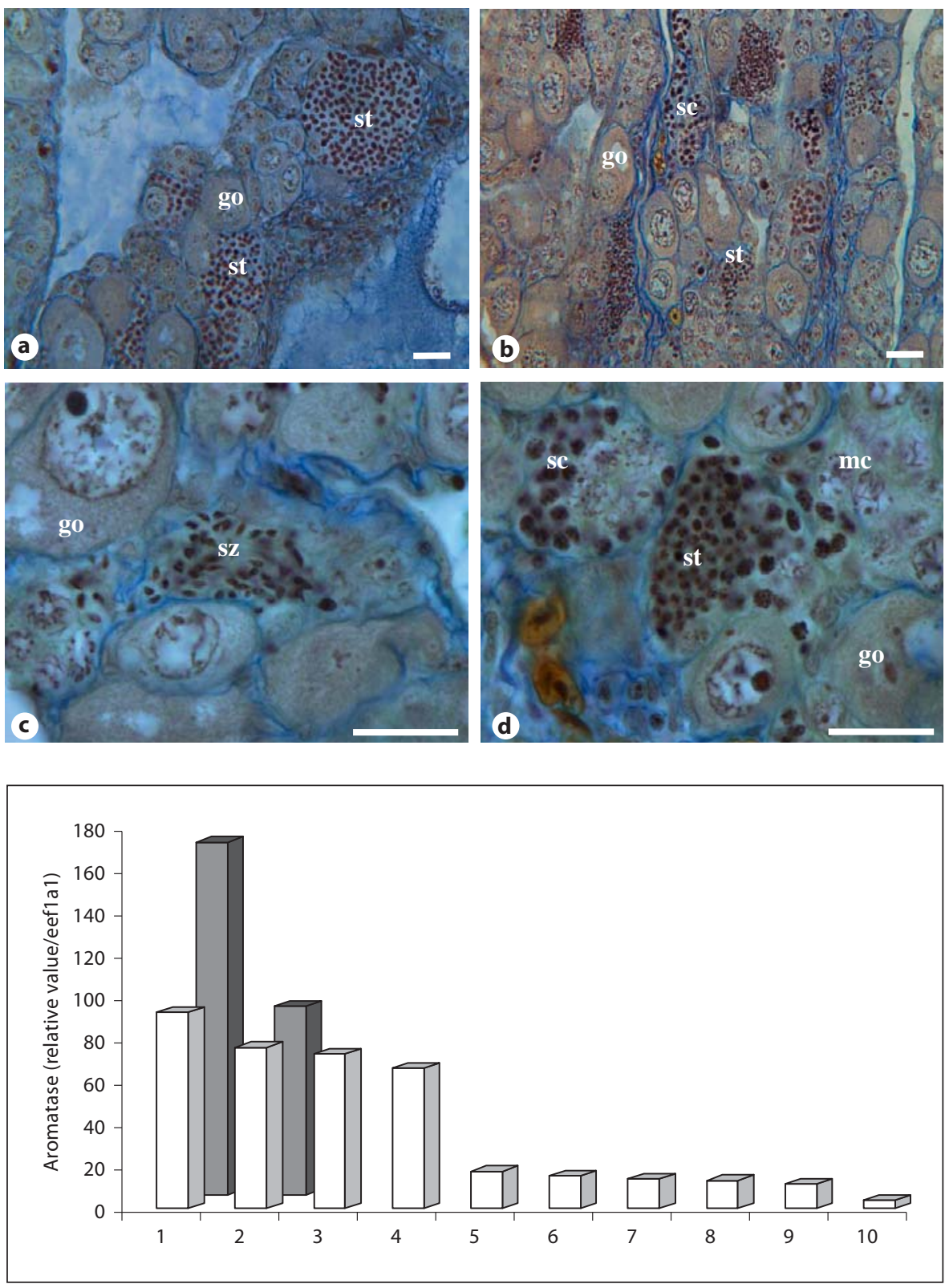

bigger $(>50 \mathrm{~cm})$ than the ones analyzed in the present experiment and their gonads looked like testes, suggesting that these individuals were at a very late stage of the development of the Syrski organ. Conversely, the gonads of the 2 intersexual European eels that we found were mostly composed of ovarian tissue, like the one observed by Lokman and Young [1998] in the New Zealand eel, $A$. dieffenbachia. It is possible that these gonads also developed via a juvenile intersexual phase as suggested for those in the experiment of Lokman and Young [1998]. In eel, the sexual differentiation is under environmental control [reviewed in Davey and Jellyman, 2005] and the period during which environmental factors act upon sex differentiation is probably quite long [Colombo and Grandi, 1996; Holmgren et al., 1997; Melia et al., 2006]. Rearing conditions of the present study could have triggered a transdifferentiation process. However, AI specimens have also been found in the wild in other eel species [Takahashi and Sugimoto, 1978; Takahashi, 1979; Lokman and Young, 1998]. One may also suggest that endocrine disruptors could have lead to the occurrence of these 2 cases, as it is known for other fish species [re- 
viewed in Bortone and Davis, 1994]. However, rearing water came from a pumping in a natural warm groundwater spring and so it appears unlikely that this water was contaminated by external chemical compounds.

The gene expression of aromatase, being known to play a major role in fish ovarian differentiation, was explored. The number of analyzed individuals was small since adult intersexuality seems to be a rare event in eels ( 2 intersexuals found among 140 fish) and, unfortunately, no statistical analysis could be performed. For whatever reason, aromatase gene expression was found to be higher in the gonads of the 2 intersexual adults when compared to most females at the same developing stage. It has been suggested that an increase in local steroid production stimulated gametogenesis in intersexual Japanese eels [Matsubara et al., 2008] and the coexistence of both testicular and ovarian tissues could enhance their respective development [Takahashi and Sugimoto,1978]. In the experiment of Takahashi and Sugimoto [1978], small pieces of gonads were sampled by laparotomy before and after an in vivo hCG treatment, allowing to follow oocyte development. Interestingly, while oocytes reached the same size in in- tersexual eels and normal females at the start of the experiment $(\sim 250 \mu \mathrm{m})$, only the oocytes of the intersexual eels entered vitellogenesis following hCG treatment (oocyte size of intersexual eel: $\sim 600-800 \mu \mathrm{m}$; oocyte size of normal female: $\sim 300 \mu \mathrm{m})$. Oocyte vitellogenesis could be triggered by the coexistence of a male tissue. Present results suggest that the upregulation of genes encoding steroidogenic enzymes, such as aromatase, might have been involved in the overdevelopment of both tissues.

\section{Acknowledgements}

B.G.'s PhD thesis was funded by Université de Pau et des Pays de l'Adour (ED 211). The project was supported by funding from the Office National de l'Eau et des Milieux Aquatiques (ONEMA) and by the Interreg IV B Atlantic area transnational program (European Regional Development Fund), in the context of the Arc Atlantic Resource Conservation program (AARC). We wish to thank Emmanuel Huchet, Jacques Rives and François Gueraud for their help in fish sampling. We are also grateful to the UR Numéa staff for their support at different steps of the experiment, and to Elodie Jouanno, Chantal Cauty, Béatrice Collin and Claude Sevellec for their support in the histological and gene expression analysis.

\section{References}

Beullens K, Eding EH, Gilson P, Ollevier F, Komen J, Richter CJ: Gonadal differentiation, intersexuality and sex ratios of European eel (Anguilla anguilla L.) maintained in captivity. Aquaculture 153:135-150 (1997).

Bortone SA, Davis WP: Fish intersexuality as indicator of environmental stress. Bioscience 44:165-172 (1994).

Colombo G, Grandi G: Histological study of the development and sex differentiation of the gonad in the European eel. J Fish Biol 48: 493-512 (1996).

Colombo G, Grandi G, Rossi R: Gonad differentiation and body growth in Anguilla anguilla L. J Fish Biol 24:215-228 (1984).

Davey AJ, Jellyman DJ: Sex determination in freshwater eels and management options for manipulation of sex. Rev Fish Biol Fish 15: 37-52 (2005).

Gabe M: Techniques histologiques (Masson et Cie, Paris 1968).

Guiguen Y, Fostier A, Piferrer F, Chang CF: Ovarian aromatase and estrogens: A pivotal role for gonadal sex differentiation and sex change in fish. Gen Comp Endocrinol 165: 352-366 (2010)

Helfman GS, Facey DJ, Hales LS Jr, Bozeman EL Jr: Reproductive ecology of the American eel. Am Fish Soc Symp 1:42-56 (1987).

Holmgren K, Wickström H, Clevestam P: Sexrelated growth of European eel, Anguilla anguilla, with focus on median silver eel age. Can J Fish Aquat Sci 54:2775-2781 (1997).
Jeng SR, Pasquier J, Yueh WS, Chen GR, Lee YH, et al: Differential regulation of the expression of cytochrome P450 aromatase, estrogen and androgen receptor subtypes in the brain-pituitary-ovarian axis of the Japanese eel (Anguilla japonica) reveals steroid dependent and independent mechanisms. Gen Comp Endocrinol 175:163-172 (2012).

Kearney M, Jeffs A, Lee P: Development and early differentiation of male gonads in farmed New Zealand shortfin eel, Anguilla australis. N Z Nat Sci 36:33-44 (2011).

Kuhlmann H: Der Einfluss von Temperatur, Futter, Grösse und Herkunft auf die sexuelle Differenzierung von Glasaalen (Anguilla anguilla). Helgol Wiss Meeresunters 27:139155 (1975).

Lokman PM, Young G: An intersexual migratory (silver) longfinned New Zealand eel and its gonadal response to treatment with salmon pituitary homogenate. J Fish Biol 52:547555 (1998).

Matsubara H, Tanaka H, Nomura K, Kobayashi T, Murashita K, et al: Occurrence of spontaneously spermiating eels in captivity. Cybium 32:174-175 (2008).

Melia P, Bevacqua D, Crivelli AJ, Panfili J, De Leo GA, Gatto M: Sex differentiation of the European eel in brackish and freshwater environments: a comparative analysis. J Fish Biol 69:1228-1235 (2006).
Olivereau M, Olivereau J: Effect of 17-alpha-methyltestosterone on the skin and gonads of fresh-water male silver eels. Gen Comp Endocrinol 57:64-71 (1985).

Satoh H, Nimura Y, Hibiya T: Sex control of the Japanese eel by an estrogen (DES-na) in feed. Nippon Suisan Gakkaishi 58:1211-1218 (1992).

Sola L, Camerini B, Cataudella S: Cytogenetics of atlantic eels - C-banding and G-banding, nucleolus organizer regions, and DNA content. Cytogenet Cell Genet 38:206-210 (1984).

Takahashi H: Two new cases of hermaphroditic gonads found in artificially matured Japanese eels, Anguilla japonica. Bull Fac Fish Hokkaido Univ 30:252-258 (1979).

Takahashi H, Sugimoto Y: Spontaneous hermaphrodite of Japanese eel, Anguilla japoni$c a$, and its artificial maturation. Jpn J Ichthyol 24:239-245 (1978).

Tesch FW: The eel, 5th ed (Blackwell Science Ltd, Oxford 2003).

Tzchori I, Degani G, Hurvitz A, Moav B: Cloning and developmental expression of the cytochrome P450 aromatase gene (CYP19) in the European eel (Anguilla anguilla). Gen Comp Endocrinol 138:271-280 (2004).

Wiberg UH: Sex determination in the European eel (Anguilla anguilla, L.). A hypothesis based on cytogenetic results, correlated with the findings of skewed sex-ratios in eel culture ponds. Cytogenet Cell Genet 36:589598 (1983). 